Michael Hanaghan*

\title{
A Metaliterary Approach to Ursicinus' Outburst (Amm. Marc. 20.2.4)
}

https://doi.org/10.1515/phil-2017-0027

\begin{abstract}
In 359 CE Constantius II appointed investigators into the fall of Amida, who confronted Ursicinus, a commander in the East, about the disaster. He refused to play along, answering them instead with a stirring outburst that predicted the imminent failure of the emperor unless he freed himself from his meddling eunuchs and his obsession with Amida. This assessment may be read as a metaliterary comment that reflects both forwards and backwards; up until that point, Constantius has been pulled along by the judgments of others, including his eunuchs, again and again. In contrast, Julian is presented as a bold and independent judge of people and events who actively carries out his responsibilities. As the narrative unfolds, Ursicinus' prediction is borne out: Constantius never gets over the fall of Amida nor the influence of his eunuchs and eventually fails. The eclipse excursus that follows enhances the prophetic force of Ursicinus' words as Julian is proclaimed Augustus and Constantius nervously dithers over what he should do. Ursicinus' outburst is crucial to his narrative role and the important intratextual links that are drawn between the main individuals in Ammianus' narrative of Constantius' fall and Julian's rise, including Gallus, Silvanus, Julian, Constantius, Eusebius, and Ammianus himself.
\end{abstract}

Keywords: Ammianus Marcellinus, Constantius II, Ursicinus, intertextuality, intratextuality, late antiquity

Coping with criticism can be hard, especially if you are a leader used to getting your way. In 359 CE Amida fell to the Persians. Ursicinus, an important leader in the Roman military, was compelled to defend himself against the imperially appointed investigators of the disaster, Arbitio and Florentius. ${ }^{1}$ According to

1 Amm. Marc. 20.2.2-4. For a detailed synopsis of Ursicinus' career see Matthews (1989) 34-37. Szidat (1996) 241 dates the investigation to November/December of 359.

*Corresponding author: Michael Hanaghan, Department of Classics, University College Cork, O’Rahilly Building, Western Rd, Cork, Ireland, E-Mail: michael.hanaghan@ucc.ie 
Ammianus the investigators were not really interested in finding out the real reason for Amida's fall, but instead targeted Ursicinus, who was decidedly unapologetic (Amm. Marc. 20.2.4): ${ }^{2}$

... sciat tamen uelut quodam praesagio, quod, dum maeret super his, quae apud Amidam gesta emendata didicit fide, dumque ad spadonum arbitrium trahitur, defrustandae Mesopotamiae proximo uere ne ipse quidem cum exercitus robore omni opitulari poterit praesens.

Let the Emperor know, as if this is a prophecy, as long as he grieves over what he has learnt happened at Amida (which is wholly absented from the truth) and as long as he is induced to adopt the judgment of eunuchs, that not even his personal presence will be able with the might of his entire army to prevent the dismemberment of Mesopotamia next spring. ${ }^{3}$

His words were reported back to the emperor, and with a little embellishment, provoked a furious response (20.2.5): iratus ultra modum Constantius "Constantius was angered beyond all measure." Perhaps in partial recognition of his years of service, or more pragmatically to stifle any unrest, Ursicinus was immediately forced into retirement. ${ }^{4}$

Ammianus could well have been present when this happened and so his version may be an accurate reflection of what Ursicinus said and did. ${ }^{5}$ If so, then Ursicinus' casting of himself in a prophetic guise was likely aimed at unnerving Constantius, who was known to apportion prophetic significance to all manner of remarks and actions. ${ }^{6}$ If not, then Ursicinus' outburst may be considered solely for its narrative effect. Of course, both of these approaches may also be considered together, namely that Ursicinus actually said these words or something similar and Ammianus chose to include them at this point in his account for

2 Amm. Marc. 20.2.4: Qua iniquitate percitus qui audiebatur 'etsi me' inquit 'despicit imperator, negotii tamen est magnitudo, ut non nisi iudicio principis nosci possit et uindicari ...' "The accused, struck by the iniquity of the situation, said 'Even though the emperor despises me, the significance of the situation is nevertheless such that it cannot be determined and dealt with one way or the other except by the emperor's judgment ...”' The Teubner edition is used throughout for Ammianus' text unless otherwise noted. All translations are my own.

3 For the force of emendata fide, literally "with the truth exiled" see Den Boeft/Den Hengst/Teitler (1987) 17. See Szidat (1996) 103-108 for a detailed historical summary of Ursicinus' confrontation.

4 Amm. Marc. 20.2.5. Blockley (1980) 476.

5 Matthews (1989) 100; see also Barnes (1998) 54; 61-62 who notes that Ammianus served on Ursicinus' staff from 354 to 359, and that he was only stationed at Antioch after Ursicinus' dismissal, and for a brief synopsis Woods (2000) 700. Ammianus' bias in favour of Ursicinus has long been noted by scholarship: see, for example, Barnes (1998) 9; 16; Kelly (2008) 38; 44-54.

6 See for example Amm. Marc. 14.5.1-4; 19.11.7. 
narrative effect. ${ }^{7}$ The incident is a rare example of when criticism managed to pierce the wall of flatterers and sycophants which surrounded Constantius.

Sidwell apportions a didactic function to this scene, arguing that Ammianus uses it to show that even capable individuals may fall if they cannot control their anger. ${ }^{8}$ She limits this interpretation to explaining Ursicinus' role but it could equally be applied to Constantius, whose inability to brook any criticism, even from one of his most capable generals, leads to a significant weakening of the Roman military leadership in the Persian campaign. ${ }^{9}$ Sidwell's argument is predicated on Ursicinus getting what he deserved, especially if he is to stand as an exemplum to others, but Ammianus tellingly focuses instead on the iniquity of Constantius' decision. ${ }^{10}$ As Kelly has argued, "the whole of Ammianus' expansive account [regarding Ursicinus] protests against the injustice of this result." ${ }^{11}$ Constantius' decision backfires; replacing Ursicinus does not result in any discernible improvement.

This article proposes that Ammianus' various depictions of characters are informed by specific intertextual allusions, principally to Virgil, and are bound to each other through sustained intratextual connections. ${ }^{12}$ The different ways that Constantius II and Julian make decisions is crucial to the contrast Ammianus develops in his narrative between the two leaders. The son of Constantine comes across as a nervous wreck, prone to second guessing, and under the spell of largely disloyal and ambitious courtiers. ${ }^{13}$ His cousin is in contrast calm, inclined - at least while Constantius is alive - to rational and considered courses of action. Whereas Constantius is often confused and hesitant, overwhelmed by an abundance of proposals from different parties each trying to further their own agenda, no-one ever seems to influence Julian's decision-making; his struggles

7 For discussion of the narrative role of this scene see below. For this approach more generally see Kelly (2008) 53-54.

8 Sidwell (2010b) 182.

9 Ammianus links Constantius to the consequences of his decisions to replace Ursicinus by repeatedly noting the incompetence of those replacements, such as Sabinianus, for which see Kelly (2008) 142.

10 Wittchow (2001) 176 notes how positive exempla like Uriscinus are set against negative equivalents, such as Constantius.

11 Sidéris (2000) 687 makes a similar case. Sabbah (1978) 439 argues that Ursicinus' earlier appearances in the narrative as a trusted agent of Constantius form a strong contrast to his final appearance.

12 Kelly (2008); Ross (2016).

13 Matthews (1989) 33: “Constantius' suspicion of political dissent, and his dependence on supporters who exploit his weakness to further their own ambitions, are central themes in Ammianus' judgment of this emperor.” 
and successes are his own, the product of careful meditation and reflection rather than the cloak and dagger intrigue that envelopes his older cousin. ${ }^{14}$

Ursicinus criticises Constantius as an inept ruler, overly reliant on the manipulative advice of his courtiers. This criticism may be read from a metaliterary perspective to reflect on the contrast Ammianus draws between Constantius and Julian, and to foreshadow, in conjunction with the eclipse excursus, Julian's rise to the purple. ${ }^{15}$ Ursicinus' role is important to Ammianus' narrative, and is a crucial link between different characters, including Gallus, Constantius, and Eusebius.

\section{1 "Ears wide open"}

The first extant scene in the Res Gestae to show Constantius' decision-making occurs at 14.5. The emperor takes rumour as fact, and on that basis convicts and tortures supposed political opponents. His violence is encouraged by his closest advisers (proximi) and flatterers (adulatores). ${ }^{16}$ This preliminary glimpse into how Constantius makes decisions includes features that recur throughout Ammianus' narrative; others manipulate him, preying on his weakness for flattery, and he shows a dangerous predilection towards inhumane punishment. In other respects, it is exceptional; Constantius does not hesitate to act, and although two types of advisers are named, the distinction between these groups is not carefully drawn. One feature, above all others, is missing: the emperor's ears.

In Ammianus' subsequent descriptions of Constantius' decision-making his ears become a contested site for the various interest groups that try to manipulate him to further their own agenda. Constantius' listening repeatedly includes mention of his ears (aures) with either the verb pateo or its etymologically related adjective patulus. A short survey may suffice:

14.11.4: Cum haec taliaque sollicitas eius aures euerberarent expositas semper eiusmodi rumoribus et patentes...

15.2.2: ... imperatoris aures occlusae patebant susurris insidiantium clandestinis ...

15.3.5: ... id uenenatis artibus coloratum in peius patulis imperatoris auribus infundebat ...

16.7.1: ... auribus Augusti confisus in omne patentibus crimen.

14 See for example Julian's decision-making while on campaign at Amm. Marc. 16.2 analysed below. This character trait is also evident in his repeated rejection of advice during his disastrous Persian campaign in book 25, such as at Amm. Marc. 25.2.7-8, although Julian's actions in that book largely correlate with the advice of his philosophers, e.g. 25.2.3; 25.3.15; 25.3.23.

15 Contra Sabbah (1978) 478; 528.

16 Amm. Marc. 14.5.1-5. 
18.3.6: ... [Barbatio] sub Augusti patulis auribus multa garriebat et saeua ...

18.4.4: ... apud principis aures nimium patulas existimationem uiri fortis inuidia graui pulsarent.

This combination of phrasing enables Ammianus to draw attention to the emperor's listening which as an intrinsically passive undertaking can be difficult to describe in active terms. In extant Latin literature the verb pateo is often found in conjunction with auris. ${ }^{17}$ Ammianus uses it somewhat unusually for Constantius by often including either a dative construction or prepositional phrase to indicate what the ears were open to, whether that be 'the secret whispering of plotters' or 'every kind of crime. ${ }^{18}$ Ammianus also uses pateo with an auditory sense without explicitly mentioning ears, as the verb can on its own mean 'ready to listen. ${ }^{19}$

The iunctura of auris and patulus is much more obscure. ${ }^{20}$ Horace uses it twice in his Epistulae, at 1.18.70 and 2.2.105. ${ }^{21}$ The first instance may shed light on the implication in Ammianus (Hor. Epist. 1.18.68-71):22

quid de quoque uiro et cui dicas, saepe uideto.

percontatorem fugito; nam garrulus idem est, nec retinent patulae commissa fideliter aures, et semel emissum uolat inreuocabile uerbum.

Always watch what you say to whom and about whom

Avoid the inquisitive man, for he is also chatty,

Receptive ears don't faithfully keep secrets,

And once a word is cast forth it flies away unable to be recalled.

Horace clearly identifies the danger that patulae aures pose..$^{23}$ The moment that the speaker says anything they have lost control. The ears of the percontator are

17 TLL s.v. lists, for example, Cic. Sull. 26; Phil. 14.20; Ov. Fast.1.181 among others.

18 Amm. Marc. 15.2.2; 16.7.1.

$19 \mathrm{~L}$ and S, pateo II.B.1 "Of the hearing, etc., to be open, ready to hear." Although, as argued here, 'ready to listen' is too neutral an expression to convey the pejorative sense with which Ammianus uses it. See, for example, Amm. Marc. 15.2.10: ex confesso pateret; 15.3.3: patebat insidiantibus multis; 26.10.12: criminantibus patens.

20 In addition to the two references to Horace, the phrase also occurs in Pomponius Mela's De Chorographia 3.48, where it is used to describe mythical beasts that can wrap themselves up in their own ears.

21 At Hor. Epist. 2.2.105 the expression auris patulas is used to refer to Horace's own ears in a moment of literary self-deprecation.

22 De Jonge (1980) 163 cites this epistle of Horace but does not use the Horatian context to inform his reading of Ammianus' tone.

23 Bowditch (1994) 423-424. 
especially dangerous as such an individual is more likely to gossip, and so may readily betray any initial confidence formed with the speaker. Porphyrio's gloss of patulae as paratae ad audiendum 'prepared to listen' marginalises the very real danger which Horace references. ${ }^{24}$

The negativity of Horace's words rings clear in Ammianus' description of Constantius' ears but the danger they pose is very different, as these are not the ears of some chatty gossipmonger but the emperor who uses the information he receives to make important political and strategic decisions with real and widespread consequences. Ammianus' focus on Constantius' gullibility puts extra attention on who his advisers were and what advice they were feeding him. His point is not that Constantius is a good listener but that he listens all too easily to the wrong people. This flaw becomes a direct threat to Ursicinus.

\section{Constantius' advisers}

Ammianus' description of Constantius' advisers falls into three categories. The first constitutes the unnamed advisers; these are the close friends (proximi), flatterers (adulatores) and eunuchs (spadones). ${ }^{25}$ It can be difficult to clearly separate these groups and it is feasible that an individual could be counted in all of them. The second category has the named advisers whose manipulation of Constantius is always negative: among these should be placed individuals like Eusebius and Arbitio. The last category consists of two advisers, the eunuch Eutherius and Constantius' wife Eusebia, both of whom are named, but unlike the second category their advice is depicted as reasonable and not aimed at furthering their own agenda.

Constantius' advisers feature prominently at four points in the narrative. At the end of book 14 they advise Constantius to move against Gallus; ${ }^{26}$ in book 15 they try to have Ursicinus implicated as a traitor, and exonerate one of their own, Gorgonius, whom Ammianus alleges was guilty. ${ }^{27}$ In book 15 and 16 Eusebia and Eutherius respectively check attempts to implicate Julian in a conspiracy against Constantius. ${ }^{28}$ Finally in book 18 the advisers manipulate Constantius' decision to recall Ursicinus from the command of the Persian campaign and then return him

24 Porphyrio commentum in Horatium Flaccum Ep. 1.18.70.

25 Tougher (1999) 66 refers to these eunuchs as "a general eunuch presence at court."

26 Amm. Marc. 14.11.1-4.

27 Amm. Marc. 15.2.1-10. Blockley (1980) 473.

28 Amm. Marc. 15.2.7; 16.7.1-3 
with the new rank of magister peditum praesentalis. ${ }^{29}$ Ursicinus is caught up in the three episodes (in books 14, 15 and 18) when the advice that Constantius receives is negative. Constantius makes other decisions that pertain to Ursicinus - towards the end of book 16, for example, Constantius decides to send Ursicinus back to his role in the east - but these decisions are presented as occurring without the manipulation of his advisers. ${ }^{30}$

Traditionally scholarship asserted that Ammianus took a dim view of eunuchs; with the prominent exception of Eutherius, as they negatively influence the emperor with plots and schemes that target the honest and let the guilty get away if it suits their own personal ambitions. ${ }^{31}$ Sidéris convincingly warns against conflating every opinion of eunuchs in the text with Ammianus' own views, arguing that “trop souvent, on ne reconnait dans ses portraits d'eunuques que le reflet des opinions des hommes sous lesquels il servit, Ursicin et Julien." ${ }^{32}$ Tougher, instead, linked the negativity of these descriptions to Ammianus' attempts to criticise Constantius II and his reign. ${ }^{33} \mathrm{~A}$ key part of this criticism is the implicit comparison between how Constantius and Julian make decisions and interact with eunuchs. ${ }^{34}$

\section{Julian vs Constantius}

Julian's decision-making forms a strong contrast to Constantius', partly because, at least in Ammianus' account, no single adviser or body of advisers feature prominently. Early in book 16 Julian decides to attack Autun. ${ }^{35}$ Flatterers fail to distract him (16.2.2): ancillari adulatione posthabita, qua eum proximi ad amoenitatem flectebant et luxum "ignoring servile flattery, with which his close advisers were trying to induce him towards pleasure and luxury." He is presented with an abundance of plans none of which are suitable until some men happen to add into the conversation (subserere) that Silvanus had recently taken a shorter but overgrown route with some difficulty. ${ }^{36}$ No clear effort is made to influence Julian

29 Amm. Marc. 18.6. Blockley (1980) 475-477; 482-483 interprets these moves as a deliberate attempt by Constantius to prevent his commanding from posing a political threat.

30 Amm. Marc. 16.10.20.

31 Matthews (1989) 274-276; for this trend see Tougher (1999) 64.

32 Sidéris (2000) 684: "Too often in his portraits of eunuchs we often see only the reflection of the opinions of the men under whom he served, namely Ursicinus and Julian."

33 Tougher (1999) 64; Sidéris (2000) 692.

34 Tougher (1999) 69-70 touches on this point.

35 Amm. Marc. 16.2.1. Ammianus credits Julian with a greater degree of authority over military matters than Julian claims to have held, for which see de Jong (1972) 13.

36 Amm. Marc. 16.2.4 
to adopt this plan, which Ammianus describes him doing on his own accord, confidently and boldly. ${ }^{37}$ Once Julian and his troops reach Rheims numerous opinions are canvassed about the best course of action, after which Julian decides to attack the Alamanni by way of the Ten Cantons. ${ }^{38}$ At no point are these decisions attributed to individuals or groups that influenced the Caesar.

Throughout the narrative of his early campaigns Julian makes his own decisions; without an array of manipulative courtiers the process can be difficult, but normally he can either grasp the best course of action straight away or deduce it after carefully canvassing for options. At arguably the most critical point in the narrative of his rivalry with Constantius Julian is left without any advisers at all. ${ }^{39}$

Following Ursicinus' outburst in book 20 Julian is ordered by Constantius to send him some troops, but Julian had recruited a number of these with the promise that they would remain on the near side of the Alps, close to their homes and families. ${ }^{40}$ His attempts to remonstrate with his tribune fail and so momentarily he is at a loss as to what to do (20.4.6.):

Et quia sollicitus Caesar, quid de residuis mitti praeceptis agi deberet, perque uarias curas animum uersans, attente negotium tractari oportere censebat, cum hinc barbara feritas, inde iussorum urgueret auctoritas, maximeque absentia magistri equitum augente dubietatem, redire ad se praefectum hortatus est ...

And because Caesar was anxious as to what ought to be done regarding the remaining troops which he had been ordered to send, turning his mind through the various concerns, he determined that situation ought to be handled carefully, since barbarian savages was pushing him one way and the authority of the orders the other, and especially as the absence of his cavalry commander was increasing his uncertainty, he encouraged his prefect to return to him ...

Bereft of both his cavalry commander and prefect Julian hesitates; his efforts to induce his prefect to return fail, and so he must decide his course of action on his own. The phrase perque uarias curas animum uersans alludes to Aeneas' difficulty at the beginning of Virgil Aeneid 8.19-21:

37 Amm. Marc. 16.2.4

38 Amm. Marc. 16.2.8-9. This was a route in Belgica I for the specifics of which see De Jonge (1972) 21. For further analysis of Ammianus' description of Julian's behaviour during this campaign see Ross (2016) 142-144.

39 Blockley (1980) 478 argues that Constantius removes Julian's friends as a way of limiting how successful he would be in his new role as a commander in Gaul, citing Julian Ep. ad. Ath. 282C and Libanius Or. 12.58, to which Julian Ep. ad. Ath. 278A-B should also be added.

40 Amm. Marc. 20.4.1-4. For discussion of the details see Sidwell (2010a) 98 and Den Boeft/Den Hengst/Teitler (1987) 58-59. 
cuncta uidens magno curarum fluctuat aestu, atque animum nunc huc celerem nunc diuidit illuc

in partisque rapit uarias perque omnia uersat ...

Seeing all of that he tosses in a great sea of worries, and directs his mind now this way and now that way and he starts off in different directions and goes over everything ...

The verbal echoes are extensive: each word in Ammianus' phrase appears in the space of three lines in Virgil's hexameters..$^{41}$ Ammianus' extensive engagement with Virgil's Aeneid, especially in the Julianic books, and the specific connection that Ammianus develops between Aeneas and Julian in his history further substantiate this textual link..$^{42}$ The situation that confronts Aeneas in Aeneid 8 is somewhat analogous to Julian's. It is becoming increasingly clear to Aeneas that the conflict with Turnus cannot be avoided, and the same may be said for Julian, who is clearly aware that refusing to comply with Constantius' orders would be a trigger for civil strife. Aeneas at this point in the epic lacks close advisers; his father Anchises is in the Underworld (Aeneas' visit to him there in book 6 was clearly a feat that could not be repeated) and he is still yet to meet Evander. Julian similarly lacks advisers, not just the kind of sycophantic courtiers that flock around Constantius, but even his leading advisers, namely his magister equitum and prefect.

Another Virgilian echo substantiates the initial allusion (20.4.9): ... Iulianus consiliorum adminiculo destitutus ancipitique sententia fluctuans id optimum factu existimavit "... Julian bereft of the help of his advisers, and wavering in anxious judgment, determined that this was the best course of action." On its own fluctuans might struggle to sustain the intertextual link, but following the clear allusion at 20.4.6 to Aen. 8.19-21, outlined above, it directly compares Julian's dilemma to Aeneas'. This is a case of what Kelly has termed 'divided intertextuality' where one single reference is split by Ammianus and used at several points in the text in close proximity to each other. ${ }^{43}$

Den Boeft, Den Hengst and Teitler also note the verbal similarity between 20.4.6: perque varias curas animum versans and Aen. 4.285-286: atque animum nunc huc celerem nunc dividit illuc / in partis rapit varias perque omnia versat. ${ }^{44}$

41 Den Boeft/Den Hengst/Teitler (1987) 65 list both Aen. 8.19-21 and 4.285-286 as references for Amm. Marc. 20.4.6: perque uarias curas animum uersans for discussion of which see below.

42 O'Brien (2006) 276-298 offers an extensive survey of Ammianus' engagement with the Aeneid in the Julianic books, but does not specifically mention this allusion.

43 Kelly (2008) 201-202.

44 Den Boeft/Den Hengst/Teitler (1987) 73-74. The intratextual connection between Aen. 4.285286 and Aen. 8.20-21 is clearly evident through Virgil's use of the same hexameters. 
Ammianus gestures specifically at Aen. 8.20-21 through his use of curarum at 20.4.6 and fluctuans at 20.4.9, both of these words appear in Aen. 8.19. ${ }^{45}$ This allusion may inform whether or not we take the resulting mutiny of his soldiers (which results in their acclamation of him as Augustus) as a spontaneous act ${ }^{46}$ or a carefully orchestrated event. ${ }^{47}$ After Aeneas' anxious stirring the river god Tiberinus tells him not to fear the threat of war and suggests Aeneas ally with the Latins to overcome Turnus. ${ }^{48}$ Aeneas equips two galleys with oars and weapons and sails off to follow through on the god's commands. ${ }^{49}$ His anxious thinking leads to a clear plan of action that is aimed at confronting his enemy directly. Ammianus' allusion to this moment in the epic hints at an awareness that Julian's actions are ultimately aimed at confronting Constantius.

The somewhat prosaic phrase at 20.4.9: id optimum factu existimauit is an intratextual allusion to Constantius' decision-making in book 14 as he ponders what he ought to do about Gallus (14.11.4): ${ }^{50}$

Cum haec taliaque sollicitas eius aures euerberarent expositas semper eiusmodi rumoribus et patentes, uaria animo tum miscente consilia, ${ }^{51}$ tandem id ut optimum factu elegit ...

When these and similar remarks struck his anxious ears, exposed and always open to rumours of that sort, after mixing up various plans in his head, finally he chose what he thought was the best course of action ...

Both men weigh their options. Julian's echoing of Aeneas' worrying lends his thoughts an epic pedigree worthy of his position. Curae are not consilia; Julian thinks through his priorities, and only then comes up with a plan. Constantius, on the other hand, has an abundance of plans, so many that he mixes them up; misceo conveys the chaos and irrationality of the various ideas as they get caught up in each other.

The two moments are Ammianus' only extant uses of the phrase id optimum factu, which might not be enough to sustain an intratextual allusion without the

45 Aen. 8.20-21 is exactly the same as Aen. 4.285-286.

46 Den Boeft/Den Hengst/Teitler (1987) 73-74: “Amm.'s continued emphasizing of Julian’s hesitation aim at persuading the reader that the pronunciamento was by no means a preconceived plan of Julian's."

47 Matthews (1997) $68 \mathrm{n}$. 69 doubts the spontaneity of the situation.

48 Aen. 8.31-65.

49 Aen. 8.79-80.

50 De Jonge (1972) 117 notes the verbal similarity of these passages.

51 The Loeb edition has been used for this phrase. 
striking similarity of Julian and Constantius' respective situations..$^{52}$ The moment in book 14 is the critical point when Constantius decides to move on Gallus, who is initially hesitant to meet him. ${ }^{53}$ Ammianus offers a withering critique of Constantius' character as the reason for Gallus' delay. ${ }^{54}$ In the end Scudillo, one of the emperor's messengers, persuades Gallus by indicating that Constantius wanted to promote him to Augustus. ${ }^{55}$ When word spreads of Gallus' behaviour which included involvement with the circus games, Constantius becomes furious (14.11.13): Quo cognito Constantius ultra mortalem modum exarsit. "Once this was discovered Constantius' rage exceeded mortal limits." 56

This is not the first time that mortal limits are exceeded in book 14. Ammianus uses the precise phrase ultra mortalem modum at another point, to describe the growing greed of Constantius' eunuchs at the very point that they first encouraged him to move against Ursicinus (14.11.3): ${ }^{57}$

Isdemque [adulatoribus] residui regii accessere spadones, quorum ea tempestate plus habendi cupiditas ultra mortalem modum adolescebat, inter ministeria uitae secretioris per arcanos susurros nutrimenta fictis criminibus subserentes ...

The remaining royal eunuchs supported the flatterers. At that time the eunuchs' desire for greed was growing beyond mortal limits, while ministering to the emperor in private by secretly whispering they added the basis for made up charges ...

This intratextual allusion binds the eunuchs to Constantius, both of whom cannot control their emotions. The events of book 20, namely Ursicinus' outburst and Julian's proclamation as Augustus act as an inverse mirror to Constantius' move against Gallus, but unlike Gallus Julian accepts Constantius' demands, and so remains ostensibly loyal until his troops unilaterally proclaim him Augustus. Julian is presented in the best possible light, as one who was not driven by ambition to seek the role of Augustus, but took it on only when there was no alternative. Constantius' action against Gallus, on the other hand, shows no

52 Ammianus regularly includes intratextual echoes at points in the text that are structurally comparable, such as his necrologies of Constantius 21.16.8: Dinumeratis ... ueniamus and Julian 25.16.4: Digestis ... ueniamus as indicated by Flower (2017).

53 Amm. Marc. 14.11.1-4.

54 Amm. Marc. 14.11.8-9.

55 Amm. Marc. 14.11.11-12.

56 Browning (1953) 18 accounts for Constantius' reaction by linking Gallus' behaviour to an expression of political support for him at these games.

57 For Ammianus' criticism of eunuchs' greed see Tougher (1999) 67. 
loyalty to his Caesar, but instead, his clear refusal to brook no rival, real or imagined, and his willingness to use deceit to ensure Gallus' downfall.

Julian's decisions are his own. The contrast with Constantius is acute. In the build up to his move against Gallus, Ammianus depicts Constantius initially (14.11.1) deliberanti cum proximis clandestinis colloquiis et nocturnis "deliberating with his closest friends, in secret conversations at night." Their plan to recall Gallus and kill him off quietly is muddied by Constantius' flatterers (14.11.2): Arbitio ad insidiandum acer et flagrans "keen and shrewd in plotting" and Eusebius effusior ad nocendum "who was overly inclined to do harm." They try to bring down Ursicinus and Gallus in the same move. The eunuchs also weighed into the process. ${ }^{58}$ The trumped up charges against Ursicinus ultimately are poured into Constantius' open ears and prompt his plan of action, Gallus is killed and Ursicinus is forced to respond to allegations of wrongdoing.

At the hearing Constantius' ears are Ursicinus' biggest problem (15.2.2):

Hac enim superabatur difficultate quod ad suscipiendas defensiones aequas et probabiles imperatoris aures occlusae patebant susurris insidiantium clandestinis ...

He was losing because of this difficulty: the ears of the emperor, although shut off to any fair and evidentiary attempts at defence but were nevertheless open to the secret whispering of plotters ...

Shadowy arrangements are made with the emperor to condemn Ursicinus to death, but then Constantius hesitates and Ursicinus gets off, saved by the bigger distraction of Julian's arrival. ${ }^{59}$ Eusebia manages to convince Constantius to appoint Julian as Caesar, and a subsequent prosecution of Gorgonius, who was, Ammianus tells us, certainly guilty of treason, fails owing to the conspiratione spadonum, the "conspiracy of the eunuchs." 60

Ammianus' account of Constantius' decision-making reflects the chaos of the process; Ursicinus is wrongly implicated, unfairly treated, and released for reasons that remain unclear or at least understated. Constantius is easily manipulated and distracted; everyone from close friends, to chief advisors, royal eunuchs, and even his wife Eusebia bend the emperor to their thinking; in the push and pull mistakes are made. Intertextual allusions colour these moments while intratextual echoes link different parts of the narrative together. Ursicinus is the constant in these episodes: when the plan to move against him is hatched in book

58 Amm. Marc. 14.11.3.

59 Amm. Marc. 15.2.5-6.

60 Amm. Marc. 15.2.10, for which see Tougher (1999) 65. 
14, when he avoids conviction in book 15 , and his final outburst before retirement in book 20. This context crucially informs Ursicinus' role as a metaliterary commentator on Ammianus' narrative.

\section{Ursicinus as Metaliterary Commentator}

Ursicinus' outburst comes at a critical point, just before the tension that has built between Julian and Constantius finally develops into direct confrontation. Sabbah argued that Ursicinus' outburst and the eclipse that follows are unconnected to the surrounding narrative of Julian's movements in Gaul, that eventually include his proclamation as Augustus. He notes "[La fonction est] d'une sorte de reprise en mains au moment critique." ${ }^{11}$ Viewing these two episodes as unconnected devalues the complexity of Ammianus' interweaving of his narrative strands, as Ursicinus' outburst looks forward to what will unfold, and the eclipse forecasts the fall of one leader and the rise of another. ${ }^{62}$

Commentators have been surprised at the ferocity of Ursicinus' criticism of Constantius and his adoption of a prophetic role. Den Boeft, Den Hengst and Teitler note:

It is surprising that these words are put into the mouth of the speaker [i.e. Ursicinus]; they would be more appropriate in the report and comments of the writer, who knowing what happens afterwards, draws the reader's attention to the prognostic character of the words of the speaker ...63

They conclude that Ursicinus' words should really be taken to indicate Ammianus' view of these events. ${ }^{64}$ If Ammianus' (sole) ambition was to provide an accurate version of events and Ursicinus did not say these words, then perhaps it is fair to cast aspersions on the 'appropriateness' of the scene, but this must be weighed alongside Ammianus' literary ambitions. Moreover, Den Boeft, Den Hengst and Teitler have no evidence to support their claim that Ursicinus did not say these words, apart from a general supposition that no commander of his rank would dare confront the emperor so starkly. Ammianus' testimony may well draw upon his eyewitness experience. ${ }^{65}$

61 Sabbah (1978) 529: "Their function is a kind of reprieve at a critical point."

62 Feichtinger (2003) 139-140 analyses the position of the eclipse excursus for its contribution to Ammianus' use of divination in his narrative.

63 Den Boeft/Den Hengst/Teitler (1987) 16.

64 Sidéris (2000) 690-691 cogently rejects that approach.

65 For further discussion of which see n. 5. 
Rather than judge this scene for its lack of appropriateness or historical realism, one can instead assess the metaliterary implications that Ursicinus' outburst has for Ammianus' narrative. Two such implications stand out: it characterises Constantius' decision-making as the product of the influence of eunuchs and foreshadows Constantius' failure to defend against Sapor's attacks. ${ }^{66}$ His comments are not simply a reflection of what has happened or will happen in the text, but spin these past and future events in specific ways.

As has been shown, the influence of eunuchs is a constant in Constantius' decision-making regarding Ursicinus. His remark ad spadonum arbitrium trahitur has received widespread interest. Matthews took it as a barb aimed specifically at Eusebius. ${ }^{67}$ Kuefler linked it directly to Eusebius' attempts to induce Ursicinus to give him one of his estates. ${ }^{68} \mathrm{He}$ surmises “Ammianus' point is clear: the power of the eunuch Eusebius was fearsome." 69 Neither of these interpretations account for spadonum being plural. ${ }^{70}$ The bigger target is not the emperor's chamberlain but Constantius himself, specifically Constantius' decision-making process which Ursicinus characterises as the "emperor being dragged along to his eunuchs' determination." 71 The specific phrase ad spadonum arbitrium occurs at one other point in Ammianus' extant books, when Constantius' eunuchs tried for a second time to implicate Ursicinus in treason against the emperor. Rumours of bad omens finally percolate through to Constantius (18.4.2): ${ }^{72}$

Et cum haec primo rumores, dein nuntii certi perferrent omnesque suspensos aduentantium calamitatum conplicaret magna formido, Comitatensis fabrica eandem incudem - ut dicitur diu noctuque tundendo ad spadonum arbitrium, imperatori suspicaci ac timido intendebat Vrsicinum uelut uultus Gorgonei toruitatem haec saepe taliaque replicans ...

When these events were reported, first by rumours, then by confirmed messages and a great terror held everyone in suspense at the impending disasters, the workshop of courtiers by hammering on the same anvil - as they say - day and night represented Ursicinus to the

66 This is clearly a different approach from conflating Ursicinus' views with Ammianus' nor it does hinge on Ammianus' invention of Ursicinus' prophetic role (Amm. Marc 20.2.4: uelut quodam praesagio).

67 Matthews (1989) 47.

68 Kuefler (2001) 68.

69 Kuefler (2001) 68.

70 Cf. Amm. Marc. 14.9.2 where Ammianus indicates that Ursicinus was undermined by aemulis consarcinantibus and not simply Eusebius.

71 As Kelly (2008) 172 has shown, Ammianus regularly depicts Constantius' officials with Plautine allusions that dwell on their upward social mobility, dangerous criminality and deceit.

72 The first occasion is at Amm. Marc. 15.2.1-6. 
suspicious and frightened emperor, in line with the judgment of the eunuchs, ${ }^{73}$ as if he was a savage faced Gorgon, repeating often these and similar accusations ...

Ursicinus' final words (in Ammianus' narrative) form an intratexual allusion to this scene, in which the eunuchs try to bring him down (again) but fail. Critically Ammianus distinguishes between the efforts of the courtiers (Comitatensis fabrica) and Eusebius, who, he alleges, was motivated to implicate Ursicinus as he wanted to acquire one of his properties. ${ }^{74}$ Eusebius is painted as the mother snake who sends out her serpent offspring to bring down her opponent (18.4.4): ${ }^{75}$

Qui ut coluber copia uirus exuberans natorum multitudinem etiam tum aegre serpentium excitans ad nocendum, ${ }^{76}$ emittebat cubicularios iam adultos, ut inter ministeria uitae secretioris gracilitate uocis semper puerilis et blandae apud principis aures nimium patulas existimationem uiri fortis inuidia graui pulsarent. Et breui iussa fecerunt.

[Eusebius] like a viper swelling with an excess of venom he arouses his band of serpent offspring, still struggling to crawl, to go and do harm. He sends out his chamberlains, now developed, ordering, while they minister to the emperor in private, that they batter with serious jealousy the reputation of that brave man into the overly open ears of their emperor, with the softness of their always boyish and fawning voices.

Ammianus presents Eusebius as the ultimate source of the moves against Ursicinus, but this knowledge is not shared by Ursicinus, who never confronts the mother snake directly, but instead fends off her offspring, until book 20, by which time he is sick of their meddling influence over Constantius. At no point is it clear that Ursicinus knows that Eusebius has been directly behind the eunuchs' efforts against him. The reader should not conflate their privileged knowledge as to who (Ammianus tells us) is really behind the efforts to bring down Ursicinus with his much more limited knowledge as to who the plotters were. If Ursicinus did in fact know that Eusebius was the ultimate source of his problems and that he coveted one of his properties, it would have made great political sense to gift it to him. Instead, Ursicinus did not gift the property to Eusebius, nor does he name him as the source of his downfall. A further intratextual allusion inter ministeria uitae secretioris binds this episode to the eunuchs' plotting in book 14, which is also directed by Eusebius.

73 The prepositional phrase ad here should be taken in conjunction with the image of the workshop, for which see L and S, s.v. D.3.y. The verb intendo has visual force here for examples of which see TLL. s.v. II.A.1.a.

74 Amm. Marc. 18.4.3. Sidéris (2000) 689.

75 Sidwell (2010b) 228 discusses other examples of Ammianus using wild animal imagery to describe the eunuchs.

76 The Loeb edition has been used for this phrase. 
Ammianus directly invokes Eusebius' role in book 14 by using the phrase ad nocendum to reference his earlier description of Eusebius as effusior ad nocendum. ${ }^{77}$

Ursicinus' prediction at 20.2.4 that Constantius will be unable to prevent Mesopotamia's losses in the following spring (i.e. the spring of 360) promptly comes true. At 20.11 Constantius personally lines up with his men against the Persian army but fails to retake Bezabde, in fact Ursicinus also gets the order correct. Constantius first passes by Amida and weeps at what he sees (20.11.5): flebat cum gemitu, a scene which Ursicinus foreshadowed in his comment (20.2.4): dum maeret super his. Constantius' eventual failure to retake Bezabde fulfils the prediction. ${ }^{78}$

Throughout the final conflict with Julian, Ammianus makes no specific mention of eunuchs that may be taken as a fulfilment of Ursicinus' claim (20.2.4): dumque ad spadonum arbitrium trahitur. Once Constantius is dead, Eusebius and some royal courtiers consider what they should do, but they are not expressly marked as spadones. ${ }^{79}$ The absence of eunuchs in Ammianus' narrative during the final months of Constantius' life may in part reflect that the important decisions were being made through consultation with the emperor's generals rather than courtiers, but Ursicinus' comments nevertheless linger whenever Constantius hesitates. Without his crowd of sycophants and eunuchs to drag him along, to pour fictitious charges into his open ears, Constantius is frequently at a loss as to what to do. Instead fate takes over Ammianus' narrative as Julian's rise continues unabated.

\section{The Eclipse}

Ammianus includes an eclipse excursus between Ursicinus' outburst and Julian's proclamation as Augustus. Ursicinus' mention of prophecy, combined with the prevalent role that omens play in Ammianus' narrative, provides ample scope to consider the eclipse excursus as foreshadowing Constantius' fall. ${ }^{80}$ This argument is cogently made by Den Boeft, Den Hengst and Teitler. Here it is substantiated by specific consideration of the excursus' 'violated chronology' and the differing

77 De Jonge (1980) 102 notes this connection.

78 Den Boeft/Den Hengst/Teitler (1987) 17 argue that Singara also fulfils Ursicinus' prediction.

79 Amm. Marc. 21.15.4.

80 Contra Sabbah (1978) 526. 
roles that omens and advisers play in affecting Julian and Constantius' decisionmaking. ${ }^{81}$

Eclipses in ancient literature regularly indicate the imminent demise of a leader. ${ }^{82}$ The excursus' position in Ammianus' narrative, immediately after Ursicinus' prophetic claims that Constantius will fail, and before Julian's proclamation as Augustus, clarifies the prophetic quality of the eclipse in the narrative that foretells Constantius' fall. It is possible that Ammianus has changed the date of the eclipse to ensure this narrative effect. The opening chapter of book 20 is set while Julian winters in Paris. ${ }^{83}$ The next chapter (Ursicinus' outburst) happens at roughly the same time. ${ }^{84}$ The eclipse then occurs in the third chapter also 'at the same time' without a precise indication of its date ${ }^{85}$ Constantius' request to Julian for troops in the fourth chapter includes demands (20.4.1): ... ut adesse possint armis primo uere mouendis in Parthos "... that they be there [in the East] to bring an attack against the Persia at the start of spring." If the position of the eclipse in the narrative reflects its chronology, as Ammianus implies, then the eclipse must have taken place at some point during the winter of 359/360 to allow sufficient time for Constantius' message to reach Julian and more importantly for the troops to relocate to the East in time for the start of spring. The kind of eclipse that Ammianus describes was a significant event, large enough to be seen throughout the East.

NASA's calculations posit that an eclipse occurred on September $9^{\text {th }} 359$ and the next eclipse was not until March $4^{\text {th }} 360 .{ }^{86}$ The former is too early to be Ammianus', the latter is too late, if, of course, Ammianus accurately reflects the eclipse's chronology, which requires that it took place before Constantius' prefect arrived to demand Julian send the requested troops in time for the start of the

81 Den Boeft/Den Hengst/Teitler (1987) 22-51 offer an extensive analysis of the eclipse, including its narrative function, but do not attempt to date it. Cf. Blockley (1972) 447 for a comparable example of Ammianus' manipulating his chronology for narrative effect.

82 Den Boeft/Den Hengst/Teitler (1987) 23-24 cite these examples of eclipses foreshadowing the death of rulers: Livy 30.38.8; 44.37.5; Plb. 29.16.6; Plu. Aem. 17; Dio Cass. 56.29.2-3; 79.30.1; [Aur. Vict.] Ep. 12.1; HA. Gd. 23.2; Aur. Vict. Caes. 41.7

83 Amm. Marc. 20.1.1: ... hiemem agens apud Parisios Caesar.

84 Amm. Marc. 20.2.1: Quae dum ita geruntur...

85 Amm. Marc. 20.3.1: Eodem tempore ...

86 NASA 'Catalogue of Solar Eclipses: 0301 to 0400' https://eclipse.gsfc.nasa.gov/SEcat5/S E0301-0400.html Accessed 3.2.17. These eclipse predictions are by Fred Espenak (NASA's GSFC). Chinese astrologers record that a major solar eclipse took place on 28 April 360, but this dating does not fit Ammianus', for which see Steele (2000) 6-7. 
spring campaign ${ }^{87}$ In any case neither of these events could have been the eclipse that Ammianus refers to as to their reconstructed eclipse paths indicate that they were only visible in Australasia. ${ }^{88}$

There are three possibilities as to why Ammianus' implied dating of the eclipse does not align with other sources: 1) the event was not really an eclipse. The first feature of the event has raised some doubts, specifically Ammianus' description of the sky being covered by a dark mist, but what then follows is a typical eclipse description: the sun is covered, and crucially it returns to sight in the progressive stages that mark an eclipse. ${ }^{89}$ This argument may thus be discounted. 2) Ammianus was provided with incorrect information. This is more plausible as Ammianus could not have seen an eclipse that fits his chronology. ${ }^{90}$ 3) Ammianus chose to insert the eclipse excursus at that precise point in the narrative so it could signal that a change in ruler was about to take place where it would foreshadow Constantius' fall and Julian's rise.

Omens play a critical role in how Ammianus describes Julian's decisionmaking; he is repeatedly presented by Ammianus as an adept reader of signs of future events except during the Persian campaign, where he repeatedly ignores indications of the future that do not enable his ambitions. ${ }^{91}$ Constantius also tries to read the future, but his efforts seem always to fail in awkward ways: Constantius ends up being right, but not in the way he intended, or lacks awareness that his predictions may be read in different ways..$^{92}$ Omens are thus a crucial counterweight to the role that advisers play in the decision-making of the two leaders. Julian's general lack of advisers (in Ammianus' account), and certainly lack of political advisers, is more than made up for by his brilliant ability to predict how events will unfold and his sagacious interaction with others who may pose a risk to him. The detrimental effect of Constantius' advisers is compounded by his inability to read the signs. His decisions are repeatedly presented as either the product of others' manipulation or his own inability. The contrast with Julian is acute; no-one manipulates him (successfully) and so he carefully follows his own

87 The eclipse on August 28, 360 is also too late to fit Ammianus' claim that the eclipse took place in the winter of 360. Barnes' (1998) 106 assessment of Ammianus' chronology is the basis for his claim that the eclipse is "imaginative fiction."

88 NASA 'Catalogue of Solar Eclipses: 0301- to 0400' https://eclipse.gsfc.nasa.gov/SEcat5/S E0301-0400.html Accessed 3.2.17 indicates the co-ordinates for both eclipses.

89 Den Boeft/Den Hengst/Teitler (1987) 22-24.

90 Den Boeft/Den Hengst/Teitler (1987) 22-24.

91 E.g. Amm. Marc. 20.5.10; 21.1.6. For examples from book 25 see n. 14.

92 Woods (2004) 167-168. Cf. Amm. Marc. 19.11.10 when Constantius incorrectly predicts that the Limigantes are about to become his subjects. 
political advice, informed by his special connection with fate and his ability to read and predict the future.

\section{Ursicinus and Gallus' 'Narrative Afterlives'}

The memory or exemplum of an individual may continue to affect a narrative even after they have died. ${ }^{93}$ Tracing the narrative role of an individual may involve going past the point of their death or their ostensible exit from the narrative. This affect has been widely understood in other genres of Latin literature. In Virgil's epic, for example, Turnus' killing of Pallas is not the end of Pallas' story as it is his sword belt on Turnus that urges Aeneas on to cut down his opponent. ${ }^{94}$ In Ammianus' Res Gestae, both Ursicinus and Gallus enjoy 'narrative afterlives' through their connections to Constantius and Eusebius.

Ammianus' account of Gallus' death in book 14 places much of the blame on the young Caesar for provoking Constantius to sentence him to death. Ammianus' account does not blame Eusebius for Gallus' death. This marks a substantial divergence from Julian's understanding of Eusebius' involvement in his brother's death which was the basis for his decision to execute Eusebius. ${ }^{95}$ So, to follow Julian in his condemnation of Eusebius, Ammianus needed to implicate him in other suitably nefarious activities, the clearest example of which is Eusebius' treatment of Ursicinus. ${ }^{96}$

Adrastia is a critical intratextual link between Gallus' death and Eusebius'; these two moments represent her only appearances in the text. After Gallus' death

93 For the use of the term narrative afterlife see Ross (2016) 75. Ross (2016) 52-95 has convincingly shown how Ammianus' adoption of the primary narrator and actor roles draw attention to Gallus and Silvanus' prefiguring of Julian. He proposed that (p. 92) “Ammianus needs Ursicinus in order to justify his own participation" however fleeting, in each of the episodes. This approach is useful for understanding how Ursicinus acts as a narrative trigger or proxy for Ammianus. Of interest here is Ursicinus' exemplum as a victim of Constantius' eunuchs, including Eusebius, and the influence this exerts on the narrative even after Ursicinus' forced retirement at the beginning of book 20. This is akin to the use of the term 'narrative afterlife.'

94 Verg. Aen. 12.941-948.

95 Sidéris (2000) 693-694.

96 Ross (2016) 91-92 links Ursicinus' presence in the narrative to Ammianus' explanation of his personal involvement as Ursicinus' protector dominus. For discussion of Ammianus' attempts to portray Uriscinus in a positive light see Sabbah (2003) 64. Ammianus' handling of Ursicinus' involvement in Silvanus' demise is a worthwhile point of comparison. As Drinkwater (1994) 573 has argued, Ammianus struggles to present Ursicinus in a positive light over what is clearly a betrayal of his friendship with Silvanus. 
she receives an extensive description (14.11.25-26) as the ultrix facinorum impiorum bonorumque praemiatrix "avenger of wicked acts and rewarder of good deeds" and regina causarum et arbitra rerum ac disceptatrix "the queen of cases, judge of affairs and arbitrator." Once Constantius is dead, Eusebius and the other eunuchs contemplate moving against Julian but their plans are foiled by his proximity. ${ }^{97}$ Julian then cleans house; a number of Constantius' advisers are tried and convicted for their part in the proceedings that led to the execution of his brother Gallus. ${ }^{98}$ Eusebius is convicted, sentenced to death and executed. Ammianus links his fate to his rejection of Adrastia (22.3.12):

... humanorum spectatrix Adrastia aurem, quod dicitur, uellens monensque, ut castigatius uiueret, reluctantem praecipitem tamquam e rupe quadam egit excelsa.

... Adrastia, the judge of human activity, pulled him by the ear, as is said, and warned him to live more moderately, but after he refused she did away with him like one thrown from off a high cliff.

Commentators have taken quod dicitur as a sign that this phrase was widely used, but it more plausibly functions as an Alexandrian footnote that alludes to the beginning of Virgil's sixth eclogue (Ecl. 6.3-5):

Cum canerem reges et proelia, Cynthius aurem
uellit, et admonuit: 'Pastorem, Tityre, pinguis
pascere oportet ouis, deductum dicere carmen.'

5

When I sang of kings and battle, Cynthian Apollo pulled me by the ear, and warned me 'A shepherd, Tityrus, ought to feed fat sheep, but sing a thin song.'

Cynthius criticises Tityrus for the incompatibility of who he is (a shepherd) and his aspiration to compose epic. By drawing the reader to the opening of this eclogue, Ammianus invokes a comparison between Apollo's treatment of Tityrus and Adrastia's treatment of Eusebius; the moralising force is felt: if Eusebius had only concerned himself with what he ought, he would not have gotten caught up in Julian's recriminations over Gallus' death. Eusebius meets his fate, deservedly, but for the wrong reason; his treatment of Gallus was fine, his handling of Ursicinus, however, demanded vengeance.

Gallus' death looms in Ammianus' description of the last omen that proceeds Constantius' death as he journeys to confront Julian (21.15.2):

97 Amm. Marc. 21.15.4.

98 Amm. Marc. 22.3.12. 
... lucente iam die cadauer hominis interfecti dextra iacens capite auulso conspexit contra occiduum latus extensum territusque omine finem parantibus fatis destinatius ipse tendebat uenitque Tarsum ...

... While the day was shining he caught sight of the body of a slain man lying on the right hand side of the road, his side stretching out towards the west: terrified by the omen, as if the fates were preparing his end, he pressed on with his journey and arrived in Tarsus.

Constantius finally, perhaps, interprets an omen correctly, reacting with terror to the decapitated corpse that presages his own death. One might be tempted to see in Ammianus' words Priam's decapitated body at Aeneid 2.554-558:

haec finis Priami fatorum, hic exitus illum

sorte tulit Troiam incensam et prolapsa uidentem

Pergama, tot quondam populis terrisque superbum

regnatorem Asiae. iacet ingens litore truncus,

auulsumque umeris caput et sine nomine corpus

This was the end of Priam's fates, this death happened to let him see Troy burnt down and Pergamum fall, once the proud ruler of so many people and lands in Asia. A big trunk lying on the shore, his head plucked from his shoulders and a body without a name.

Perhaps there are only so many words that can be used to describe a decapitated body lying on the ground, and so there is not sufficient verbal specificity to link the two images. This must be balanced against the suitability of the comparison. If Constantius' terrified reaction is because he links his fate to the corpse's, then Constantius takes on the role of doomed Priam to Julian's Aeneas. ${ }^{99}$ The level of detail that Ammianus provides is striking; it is not simply that Constantius saw a corpse, but that he saw a decapitated corpse, and while decapitation does not feature heavily in Ammianus' narrative, it is part of the detail that Constantius offers about Gallus' execution (14.11.23):

... et ita colligatis manibus in modum noxii cuiusdam latronis ceruice abscisa ereptaque uultus et capitis dignitate cadauer est relictum informe paulo ante urbibus et prouinciis formidatum.

... and once his hand had been tied behind his back in the manner of some sort of guilty robber and he was decapitated, his face and head were mutilated, and his misshapen body was left behind, until recently a terror to cities and provinces.

99 See O'Brien (2006) 276-282 for Ammianus' casting of Julian as Aeneas elsewhere in the narrative. 
A lack of verbal similarity regarding the specifics of Gallus' decapitation does not help further the link, although it does show that the similarities between Constantius' prophetic roadside victim and Priam ought not to be discarded. There is also a striking syntactical parallel between Priam's description tot quondam populis terrisque superbum and Gallus' paulo ante urbibus et prouinciis formidatum, which are both in the form adverb, adverb, dative plural co-ordinated to another dative plural, adjective. The parallel invites a comparison between the intertwined destinies of Priam and Aeneas, and Gallus and Julian. For one to succeed, the other had to fail, but this failure ultimately is out of their hands, as events unfold so that Aeneas/Julian may fulfil their respective fates.

\section{Conclusion}

Scholars have become wedded to the idea that Ammianus' portrayal of Ursicinus is an example of his personal bias. ${ }^{100}$ This bias supposedly induced Ammianus to criticise Ursicinus' opponents, whether eunuchs ${ }^{101}$ or Constantius himself. ${ }^{102}$ But this assessment may easily be flipped, to claim that Ammianus portrays Ursicinus as a hero to impugn the enemies of his main hero, Julian, foremost among whom are Constantius and his meddling eunuchs. ${ }^{103}$ By binding together Constantius' decision-making and the eunuchs' influence it becomes harder to tell which decisions were whose.

Ursicinus' criticism of Constantius being pulled one way and then another by eunuchs (20.2.4: ad spadonum arbitrium trahitur) is a fair assessment of how Ammianus portrays his decision-making. Time and time again the emperor is manipulated, fed half-truths, disinformation and alternative facts. Constantius comes across as a gullible princeps surrounded by devious and ambitious eunuchs.

Ammianus uses intertextual allusions to colour these passages, as Julian's worrying mirrors Aeneas', Gallus' death takes on shades of Priam, Adrastia mimics Cynthius, and Constantius' ears lie open like Horace's percontator. Intra-

100 Momigliano (1974) 1400: “... the only man for whom Ammianus shows real devotion and for whom his eulogy is both consistent and sincere is his old patron Ursicinus, an intriguer and a bad general."

101 Tougher (1999) 68. Sidéris (2000) 686 suggests that Ammianus' criticism of eunuchs could stem from their final treatment of Ursicinus, and so to prove his innocence, Ammianus presents a consistently negative portrayal of their actions.

102 Barnes (1998) 16.

103 Tougher (1999) 71. 
textual echoes form important links that connect Ursicinus and other characters in Ammianus' narrative including Constantius, Julian, Gallus and Eusebius.

Ursicinus' predictions come true: Constantius proves himself unable to get over the fall of Amida and the influence of his meddling advisers. Eusebius is cast as the source of Ursicinus' downfall, but whether Ursicinus ever knew that is unclear. His words and the eclipse excursus cast a shadow over Constantius' actions, as he hesitates, anxiously and nervously tries to determine the best course of action, until fate intervenes and the omens that presage his death overwhelm him.

Acknowledgments: I would like to thank Catherine Ware for inviting me to give an earlier version of this paper in the 'Literature and the Classical Tradition' seminar series at University College Cork. I am grateful to David Woods, Alan Ross, and the two anonymous Philologus reviewers for their comments, and to the Irish Research Council for their financial support.

\section{Bibliography}

Q. Horatius Flaccus, Epistles Book 1, ed. R. Mayer, Cambridge 1994.

Ammianus Marcellinus, Rerum gestarum libri qui supersunt, ed. W. Seyfarth, Leipzig 1978.

Ammianus Marcellinus, Rerum gestarum libri qui supersunt, ed. J. C. Wolfe, Cambridge, MA/ London 1940.

P. Vergili Maronis Opera, ed. R. A. B. Mynors, Oxford 1969.

T. D. Barnes, Ammianus Marcellinus and the Representation of Historical Reality, Ithaca/London 1998.

R. C. Blockley, “Constantius Gallus and Julian as Caesars of Constantius II”, Latomus 31.2, 1972, 433-468.

R. C. Blockley, “Constantius II and his generals”, in: C. Deroux (ed.), Studies in Latin Literature and Roman History II, Bruxelles 1980, 467-486.

J. den Boeft/D. den Hengst/H. C. Teitler, Philological and Historical Commentary on Ammianus Marcellinus XX, Groningen 1987.

J. den Boeft/D. den Hengst/H. C. Teitler, Philological and Historical Commentary on Ammianus Marcellinus XXI, Groningen 1991.

J. den Boeft/D. den Hengst/H. C. Teitler, Philological and Historical Commentary on Ammianus Marcellinus XXII, Groningen 1995.

L. Bowditch, “Horace's Poetics of Political Integrity: Epistle 1.18”, AJPh 115.3, 1994, 409-426.

R. Browning, "The Riot of A.D. 387 in Antioch: The Role of the Theatrical Claques in the Later Empire”, JRS 42, 1952, 13-20.

J. F. Drinkwater, "Silvanus, Ursicinus and Ammianus Marcellinus: fact or fiction?”, in: C. Deroux (ed.), Studies in Latin Literature and Roman History II, Bruxelles 1994, 568-576.

F. Espenak, NASA 'Catalogue of Solar Eclipses: 0301 to 0400’ https://eclipse.gsfc.nasa.gov/SEc at5/SE0301-0400.html Accessed 3.2.17. 
H. Feichtinger, "Doctrinae genus haud leve. Der Exkurs über Weissagung in den Res Gestae des Ammianus Marcellinus (XXI, 1, 6-14)”, Römische Quartalschrift 98, 2003, 137-161.

R. Flower, "TAMQVAM FIGMENTVM HOMINIS: Ammianus, Constantius II and the Portrayal of Imperial Ritual”, Classical Quarterly 65.2, 2015, 822-835.

R. Flower, “The Unstable World of Ammianus' Constantius”, Constantius II Research Seminar, University College Cork 2017.

P. de Jonge, Philological and Historical Commentary on Ammianus Marcellinus XIV.1-6, Groningen 1935 (= 1972).

P. de Jonge, Philological and Historical Commentary on Ammianus Marcellinus XIV.7-12, Groningen 1939 (=1972).

P. de Jonge, Philological and Historical Commentary on Ammianus Marcellinus XV.1-5, Groningen 1948 (= 1972).

P. de Jonge, Philological and Historical Commentary on Ammianus Marcellinus XV.6-13, Groningen 1953 (= 1972).

P. de Jonge, Philological and Historical Commentary on Ammianus Marcellinus XVI, Groningen 1972.

P. de Jonge, Philological and Historical Commentary on Ammianus Marcellinus XVII, Groningen 1977.

P. de Jonge, Philological and Historical Commentary on Ammianus Marcellinus XVIII, Groningen 1980 a.

P. de Jonge, Philological and Historical Commentary on Ammianus Marcellinus XIX, Groningen $1980 \mathrm{~b}$.

G. Kelly, “The Great Tsunami”, JRS 94, 2004, 141-167.

G. Kelly, Ammianus the Allusive Historian, Cambridge 2008.

M. Kuefler, The Manly Eunuch, Masculinity, Gender Ambiguity, and Christian Ideology in Late Antiquity, Chicago 2001.

J. Matthews, The Roman Empire of Ammianus, Baltimore 1989.

A. Momigliano, "The Lonely Historian Ammianus Marcellinus", Annali della Scuola Normale Superiore di Pisa. Classe di Lettere e Filosofia 3.4.4, 1974, 1393-1407.

D. C. Nutt, "Silvanus and the Emperor Constantius II", Antichthon 7, 1973, 80-89.

P. O’Brien, “Ammianus Epicus: Virgilian Allusion in the Res Gestae”, Phoenix 60, 2006, 274-302.

A. Ross, Ammianus' Julian: Narrative and Genre in the Res Gestae, Oxford 2016.

G. Sabbah, La méthode d Ammien Marcellin. Recherches sur la construction du discours historique dans les Res gestae, Paris 1978.

G. Sabbah, “Ammianus Marcellinus”, in: G. Marasco (ed.), Greek and Roman Historiography in Late Antiquity, Fourth to Sixth Century A.D., Leiden 2003, 43-84.

G. Sidéris, "La comédie des castrats. Ammien Marcellin et les eunuques, entre eunucophobie et admiration", Revue belge de philologie et d'histoire 78.3-4, 2000, 681-717.

B. Sidwell, "Insult and Outrage and the Roman Military: Ammianus Marcellinus 'Res Gestae' 20.8.8; 25.3.10; 28.6.23”, in: B. Sidwell/D. Dzino (eds.), Studies in Emotions and Power in the Late Roman World. Papers in honour of Ron Newbold, Piscataway 2010a, 87-110.

B. Sidwell, The Portrayal and Role of Anger in the Res Gestae of Ammianus Marcellinus, Piscataway 2010 b.

J. M. Steele, Observations and Predictions of Eclipse Times by Early Astronomers, Dordrecht 2000.

J. Szidat, Historischer Kommentar zu Ammianus Marcellinus Buch XX-XXI, Teil III: Die Konfrontation, Stuttgart 1996. 
S. Tougher, “Ammianus and the eunuchs”, in: J.W. Drijvers/D. Hunt (eds.), The Late Roman World and its Historian: Interpreting Ammianus Marcellinus, London/New York 1999, 64-74.

M. Whitby, “Images of Constantius”, in: J. W. Drijvers/D. Hunt (eds.), The Late Roman World and its Historian: Interpreting Ammianus Marcellinus, London/New York 1999, 77-88.

S. R. Williams, "Ammianus and Constantius: The Portrayal of a Tyrant in the Res Gestae", Diss. University of Tennessee 2009.

F. Wittchow, Exemplarisches Erzählen bei Ammianus Marcellinus, Leipzig 2001.

D. Woods, “Ammianus Marcellinus and the Rex Alemannorum Vadomarius", Mnemosyne 53.6, 2000, 690-711.

D. Woods, "Notes and Discussions: Ammianus Marcellinus 21.6.3: A Misunderstood Omen", CPhil 99, 2004, 167-168. 